2020, Volume 14, International Conference Innovative Business Management \& Global Entrepreneurship (IBMAGE 2020), pages: 661-669 |

https://doi.org/10.18662/lumproc/ibmage2020/48

\section{Methods, \\ Techniques and Sales Strategies}

\section{Cristina Gabriela VASCIUC (SĂNDULESCU) ${ }^{1 *}$, Dumitru SĂNDULESCU² Otilia CRĂCIUN (RADU) ${ }^{3}$}

1 Valahia University of Târgoviște, Romania, crisabebe2005@,yahoo.com

* Corresponding Author

${ }^{2}$ Valahia University of Târgoviște, Romania, miti.sandulescu@yahoo.com

${ }^{3}$ Valahia University of Târgoviște, Romania, România, otiliaradu@yahoo.com
Abstract: The economic life implies the existence of the actors who have to satisfy their own needs, expectations, this presupposing the appearance of the choices that they must make from the multitude of products or services on the market.

Since ancient times, the sale has been made for a better living, so Thales is the first wise, Solon the second founder of Athens and the mathematician Hippocrates, who were traders. Plato, the divine, sold oil, and Baruch Spinoza, philosopher, polished mirrors. Therefore, sales forces play an important role, which, through their strategies, can make a significant contribution to achieving the general and specific objectives. The art of selling tips the balance of success and failure, the relationship between the seller and the client, ending with win-win situation for both parties.

Keywords: Sales; goods production; organization; profit; strategies.

How to cite: Vasciuc (Săndulescu), C.G., Săndulescu, D., \& Crăciun (Radu), O. (2020). Methods, Techniques and Sales Strategies. In M. W. Staniewski, V. Vasile, \& A. Grigorescu (vol. ed.), Lumen Proceedings: Vol. 14. International Conference Innovative Business Management \& Global Entrepreneurship (IBMAGE 2020) (pp. 661-669). Iasi, Romania: LUMEN Publishing House.

https://doi.org/10.18662/lumproc/ibmage2020/48 


\section{Introduction}

Sales strategies, as subordinated marketing strategies, are challenging for the organization, but especially for those who adopt them within it. This implies identifying the demand segment according to the company's offer, but above all emphasizing the product or service qualities offered by sales agents who need to be trained to achieve the expected results. Sales force must apply appropriate strategies for each client, without misleading the client.

Thus, the purpose of marketing strategies is to determine customers to buy products or services offered by the company through determined, persistent, optimistic, experienced, experienced sales agents. Customers are looking for products or services that promise the highest quality, high degree of innovation, so companies should permanently improve their manufacturing process and necessarily the product itself, hence the productoriented concept. At the same time, there is another option, that of sales orientation, which focuses products or services without search too much, in this case, clients need to be identified and convinced to buy their benefits.

\section{Sales lead the business}

Any business has a central core which is the idea of selling. The ability to sell all sorts of goods, products and services is essential for any business and of course it implies the idea of selling yourself. As a sales agent in business, the business must be visible. You become the expert who meets the needs and wishes of your customers.

The art of selling implies discovering the customer's needs and wants and the way that you treat your customers creates a positive impression in what concerns the business. This way, the customer is provided with a picture of what he/she wants to purchase and the act of selling will take place only by implying the ability to properly handle the relation customersalesperson.

For a better selling of the product it is necessary that you hire a person who has the best qualities for learning everything about the product that he sells and he is also very good in relating directly or indirectly with the customer.

Nowadays, the entrepreneurs must take into consideration the customers' cultural particularities, their incomes, their jobs and thus making the selling possible in a very distinct way.

Customer relationships play an essential role in successful sales. Ruth and Wysoki consider that the selling itself is not as important as the relation 
developed between the customer and the seller [4]. This is why it is necessary to gain customer's trust, this happening through a very close observation of his expectations, everything expressing through an attentive listening of what he says. Taking all this into consideration, the way a seller chooses to communicate with a potential buyer can lead to an excellent relation with him, increasing the selling and the company's profits.

Ken Blanchard, co-author of "Raving Fans", argues the fact that for having a major advantage in front of the competitors, the seller must take the customer to the point that he would be much honoured to have their products and brag about it to their friends [9].

\section{Potential sales}

Networking creates potential customers who can help your business to grow in sales.

Networking will expand contacts to find services that would help with the business. Two types of networks will improve your sales skills. The first is the official network where people come from commercial or professional associations with similar business interests together (such as the Local Chamber of Commerce) [7]. The second type is the informal network that involves other people with other companies (such as managers, sellers, and even competitors).

\section{Steps to close the sale}

The negative experiences make the customers feel uncomfortable, a less experienced seller could even put up some major risks, including the decreasing of the profit.

There are seven steps to the sales process: prospecting, preparing, approaching, presenting, addressing objections, closing sales and tracking [11]:

1. Prospecting - identifying the customers.

2. Preparing - the knowledge you get about a customer after prospecting .

3. The sales approach - the very important, this way the seller has a first occasion to make a good impression.

4. Presenting sales - presenting the benefits of the products or services to the customers to maintain a steady interest.

5. Managing objections or rejection - handling rejections involves the ability of the seller to foretell possible objections such as: no need, no hurry to buy, no trust, no money to buy, and no desire to buy.

6. Closing sales - it takes place when the client buys the product, even if the seller has to use an emotional motivation. 
7. Finally, the customer must be followed by the seller, even after the deal was signed.

\section{Sales rules}

1. Any business has a central focus - the customer

2. The business needs the customer

3. The business's goal is relating to the customer

4. For the business, the customer is a stakeholder

5. The business is there for the customer's needs

6. The business takes into consideration that the customers have different expectations

7. The business must overcome a customer's objections

8. The business has obvious advantages if it also offers extra benefits

9. The business must maintain its customers

10. The business exists due to the customer

\section{Sales Strategies}

- Selling to current clients = loyalty group towards the company, creating a positive feedback between them and the company or between them and the sales agent

- Cross selling strategy $=$ sharing of complementary products of the same brand. This means inducing the customer's message that he needs all of those products, helping the seller in the sales process. Applies well on the service area: printing houses, hotels, restaurants

- The up-selling strategy $=$ convincing the customer to buy a more expensive product than the one for which he has shown his desire to purchase. Assumes the salesperson's tactic to ask and learn about customer needs $[1 ; 12]$.

Today's businesses have begun to focus on customer relationship marketing, this assuming the loyalty of existing customers, maintaining longlasting relationships with them, giving them added value and satisfaction. Due to different preferences and changes in consumer tastes, organizations come to their satisfaction with complementary products that increase the desire to purchase, so their satisfaction attracts other customers [2]. At the same time, the customer loyalty differs greatly depending on the competitive situation, the influence of the clients' product characteristics being very high, as well as the changes in the income structure, some of the consumers being cautious about spending, others with "handshake".

Customer relationship marketing also involves employing those people trained in product and service knowledge to inform customers about 
product characteristics, novelty, and significant differences from a similar product [3].

Seller and customer communication is important, with an influence on the seller's sales and the customer: the seller will explain to the customer what he or she knows best about everything and the customer will be delighted that the communicator is competent, appreciating this, having the desire to return to the space where he was best informed.

Customers differ in many ways: there are children, adults, elderly people who have expectations, desires, different needs depending on sex, occupation, temperament, character, income, ethnicity, so sales forces need to know to correctly inform in terms of their own offer, correctly identify customers' expectations and intervene when customers change their tastes [10].

Organizations are becoming more and more interested in improving their communication with consumers, contributing significantly to increasing revenue for organizations, promoting new products on the market, selecting those consumers interested in the product or service, creating customer relationships, etc. . On the other hand, customer satisfaction becomes an opportunity for the company, attracting other potential buyers [14].

Sales strategies are true works of art, especially nowadays, when customers are increasingly paying attention to how they spend their income, so long-term relationships with consumers have to be built and they have always used favourable customer reviews have purchased the company's products or services [6].

The company's marketing department is the only one that generates profit, so it has to propose SMART (specific, measurable, applicable, realistic, and time-limited) goals, see Figure 1 [15].

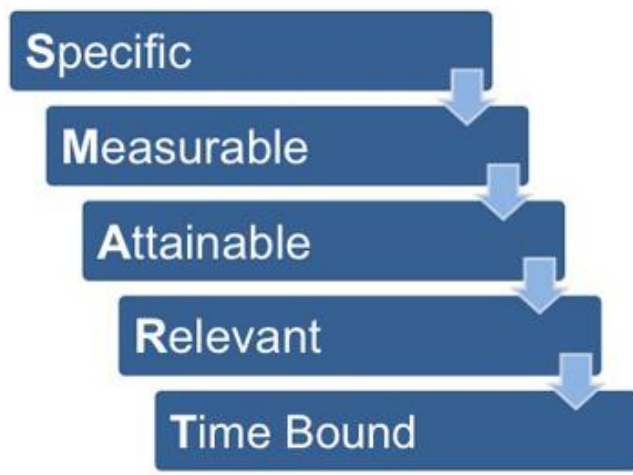

Source:SMART [15]

Figure 1 SMART goals 
Sales people should have attitudes, skills, and sales knowledge to observe the customer's behaviour to discover his needs to interact with it.

Selling the product involves presenting the product's features by describing its features so that customer demand is secure [5].

"The unilateral sale method requires the seller to focus on product presentation, insisting on its features, not being interested in the customer's actual purchasing motives. This method does not allow real exchange of information, effective communication between the seller and the customer" [8]

"The bilateral sales method is based on the existence of a flow of information between the seller and the comparator potential, both partners being involved in the communication process. Thus, the seller identifies the buyer's reasons and the customer's needs, subsequently making a presentation of the product focused on the customer ", see Figure 2 [8].

\section{METHODS}

\begin{tabular}{|c|c|c|}
\hline Tasks & $\begin{array}{l}\text { Asking } \\
\text { Explore } \\
\text { Discuss } \\
\end{array}$ & $\begin{array}{l}\text { Demonstrate } \\
\text { Exploring } \\
\text { Explain }\end{array}$ \\
\hline \multirow{2}{*}{$\begin{array}{l}\text { The sales concept that } \\
\text { is supposed to be done: } \\
\text { Results - to sell the } \\
\text { product. } \\
\text { What is it? } \\
\text { How does it work? }\end{array}$} & $\begin{array}{l}\text { THE CONCEPT OF } \\
\text { SALE } \\
\text { Bilateral Form } \\
\text { (discussing possible } \\
\text { outcomes and } \\
\text { discrepancies) } \\
\text { "What's the bigger thing } \\
\text { for you?" }\end{array}$ & $\begin{array}{l}\text { THE CONCEPT OF } \\
\text { SALE } \\
\text { Unilateral (presentation } \\
\text { of benefits) "Allow me } \\
\text { to explain how the } \\
\text { quality will grow" }\end{array}$ \\
\hline & $\begin{array}{c}\text { SELLING THE } \\
\text { PRODUCT } \\
\text { Bilateral form } \\
\text { (discussing product } \\
\text { modes) } \\
\text { "What features are you } \\
\text { looking for?" }\end{array}$ & $\begin{array}{c}\text { SELLING THE } \\
\text { PRODUCT } \\
\text { Unilateral (Presentation } \\
\text { of features, traits) } \\
\text { "Let me describe this } \\
\text { aspect" }\end{array}$ \\
\hline
\end{tabular}

Source: Robert B. Miller, Stephen E. Heimon, La Venta Conceptual, Ediciones Folio, Barcelona, 1989, p181 [8]

Figure 2. Planning Matrix 


\section{Methodology of research}

Choosing the "Selling Methods, Techniques, and Strategies" is a challenge for the marketing environment because many of the indigenous organizations approve this issue only through accelerated sales growth, profit making, not taking into account the need to generate sales. Now anything will sell to anybody, however much, thus predominantly an intense production.

The main purpose of the paper is to identify the sales strategies used by the companies in the market in order to achieve the general and specific objectives, which will bring added value and the newcomers to the marketing companies.

During the work, we used bibliographic sources belonging to the Romanian and foreign specialized literature, digital library sources and internet pages, which together with their own experience contributed to the shaping of aspects of the sales vision.

\section{Conclusions}

The role of sales is well established within the marketing mix, which contributes significantly to the objectives of organizations. The sale is based on a lot of actions such as creating, distributing and even consuming the good or service. In this respect, the seller is assigned sales techniques that describe clear and real images of products or services in order to be purchased by the customer. Thus communication between sales forces and buyers must materialize in the act of sale-purchase. The art of selling involves building trust with customers, and sellers need to know the strengths they can offer. Changes that occur on the market are subordinate to marketing activities, so their central purpose lies with the customer's orientation, needs, needs, expectations, these actions leading to maximizing satisfaction, consumption and why not the quality of life.

\section{Acknowledgement}

This work is supported by project POCU 125040, entitled "Development of the tertiary university education to support the economic growth PROGRESSIO", co-financed by the European Social Fund under the Human Capital Operational Program 2014-2020 


\section{References}

[1] Alvani S, Azar A, Danaeifard H. Quantitative research methodology in management: A comprehensive approach, Tehran: Saffar Publication. 2004.

[2] Anderson JC, Narus JA, Wouters M. Tiebreaker selling: How nonstrategic suppliers can help customers solve important problems. Harvard Business Review [Internet]. 2014 [cited 2020 Oct 15];92(3). Available from: https://hbr.org/2014/03/tiebreaker-selling

[3] Bosworth MT. Solution selling: Creating buyers in difficult selling markets. 1st ed. McGraw-Hill Education; 1994. 224 p.

[4] Creswell JW. Research design: Qualitative, quantitative, and mixed methods approaches. Singapore: Sage publications; 2013. 273 p.

[5] Croitoru G, Radu F, Nitu O, Tileaga C. Ways to Increase the Efficiency of Recruitment, Selection and Employment Strategies in Large Organizations from Dambovita County. Risk in Contemporary Economy. Proceedings conference [Internet]. 2012 [cited 2020 Oct 15];2067:219-224. Available from: https://ideas.repec.org/a/ddj/fserec/y2012p219-224.html

[6] DeVincentis JR, Rackham N. Breadth of a salesman: But even in the same industry, different customers see value very differently. McKinsey Quarterly. 1998; p. 32.

[7] Johnson JS. Broadening the application of mixed methods in sales research. Journal of Personal Selling \& Sales Management [nternet]. 2015 [cited 2020 Oct 19];35(4):334-345. Available from: https://doi.org/10.1080/08853134.2015.1016953

[8] Miller R B, Heimon SE. La Venta Conceptual. Barcelona: Ediciones Folio; 1989. $181 \mathrm{p}$.

[9] Nicodim L, Croitoru G, Radu F. Sales Management-Essential Factor for Contemporary Companies Competitiveness. Economic Sciences Series. 2012;12(1):1052-1055.

[10] Radu V, Florea NV, Radu F, Tabirca AI. Improving Long-Term Relationships between Organizations and Customers using Marketing Databases and Simulation Models. Journal of Science and Arts [Internet]. 2020 Apr [cited 2020 Oct 19];20(2):395-418. Available from: http://www.josa.ro/en/index.html?http\%3A//www.josa.ro/en/josa.html

[11] Cashing in on. Business opportunities [Internet]. Southern Rural Development Center. Available from: http://srdc.msstate.edu/cashing/files/p2 7 selling.pdf

[12] Moisan A. 4 metode eficiente de creștere a vânzărilor [Internet]. Manager.ro Portalul tău de știri [updated 2017 Sep 29; cited 2019 Feb 21]. Available from: https://www.manager.ro/articole/marketing-18/4-metode-eficiente-decrestere-a-vanzarilor- $77377 . \mathrm{html}$ 
[13] Făcăleaţă LI. Perspective ale pieței româneşti de retail în contextul Europei 2020. Stategii manageriale [Internet] 2015 [cited 2020 Aug 22] Available from: http://www.strategiimanageriale.ro/article-2015-id-67-revista.nr..2.(28)-393perspective.ale.pietei.romanesti.de.retail..in.contextul.europei.2020.html

[14] Anghel LD, Tehnici de promovare. Note de curs. [Internet]. [cited 25 Mar, 2019] Available from:

http://www.langhel.ase.ro/tehnici\%20promotionale\%202009.pdf

[15] SMART - Specific Measurable Achievable Realistic Timely [Internet]. Free Management eBooks, Templates and Checklists. [cited 2020 Aug 19] Available from http://www.free-management-ebooks.com/faqps/goal-04.htm 